\title{
THE ANALYSIS OF PERSONAL DEIXIS IN THE "KAIWA" PRACTICE OF THE FIFTH SEMESTER STUDENTS OF JAPANESE EDUCATION PROGRAM IN UNNES
}

\author{
Maulidyawan Dian Danendra1, Silvia Nurhayati, S.Pd., M.Pd. ${ }^{2}$

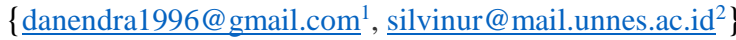 \\ ${ }^{1,2}$ Universitas Negeri Semarang, Semarang, Indonesia
}

\begin{abstract}
Deixis is used for showing and explaining personal, place, time, and the other grammatical variety, which is connected directly in some circumstances. Deixis and pronoun are so related. Japanese has so much type of personal pronouns such as 私/Watashi and 僕/Boku mean “I”、貴様/kisama and あなた/anata mean you, あいつ/aitsu こいつ/koitsu mean this or that person, and many more. Nevertheless, it depends on the situation and status of the participant in the dialogue. Some of the 2018/2019 fifth semester students of UNNES had taken the basic linguistic subject. However, they got difficulty with the function of personal deixis. The goal of this paper is to explain the form and the function of personal deixis in kaiwa or Japanese conversation practice of the fifth semester students of the Japanese Education Program in UNNES. This paper is using descriptive and qualitative analysis. This paper uses listening involving and speaking techniques to collect the data. This paper also uses the video of the kaiwa or Japanese Conversation practice of the 2018/2019 fifth semester students of the Japanese Education Program in UNNES. The theory of Levinson is used to analyze the data. Based on data analysis, personal deixis that is used by the students is 俺/ore. It functions to express first personal deixis. The second is 君/Kimi. It means "you" that refers to the second speaker. The third is 隣の人/tonari no hito, which means the next person, refers to the person outside the dialogue.
\end{abstract}

Keywords: deixis, personal, Japanese.

\section{INTRODUCTION}

Language is a means of communication, which is used by humans to make an interaction with others. Indeed, when people are talking, language is an important part of the interaction and has a very important role. In this case, language has some functions such as asking, giving the opinion, greeting someone, and many more. Therefore, without language, they cannot express feeling to others. 
This paper concerns about pragmatics. Pragmatics is one of the linguistic branches. Pragmatic is a study of relations between language and context. In pragmatic, there is a topic, which is called deixis. Deixis means something that is pointed inside the dialogue. Likewise, in English, Indonesia, and Japanese dialogue, people always point pronouns such as personal, time, and place. In Japanese, a noun is called as 名詞/meishi. There are first personal, second personal, and third personal terms in deixis. However, Japanese has so many varieties of the personal pronoun. For example, 私/Watashi and 僕/Boku mean “I”、貴様/kisama and あなた/anata mean you, あいつ/aitsuこいつ/koitsu mean this or that person, and many more. Their usage depends on the situation and status of the participant in the dialogue.

In the structure of the curriculum in the Japanese Education Departement of UNNES or Semarang State University, there is a kaiwa or Japanese conversation subject. Students of the 2018/2019 fifth semester are asked to do the conversation in pairs or groups based on the roleplay. During the conversation, personal deixis always appears. Therefore this paper is intended to study personal deixis in Japanese Conversation.

Students of the 2018/2019 fifth semester had taken the basic linguistic subject. They learned about morphology, semantics, syntax, pragmatics, and letter. Students used the "Pesona Bahasa" book as a module. However, the function in this book is not complete in deixis. Therefore students get difficulties to understand the concept of deixis even though students have to practice to use deixis.

Deixis is defined as word or phrase (such as this, that, these, those, now, then, here) that points to time, place, or situation in which a speaker is speaking[1]. This paper concerns with personal deixis only. It encodes the participants' roles in a speech event and shows itself typically in personal and possessive pronouns ${ }^{[1]}$. There are three kinds of personal deixis, i.e., 1) First personal deixis, Deixis, which function is for pointing the first person (speaker), or the speaker itself. 2) Second personal deixis, Deixis, which functions to point the second speaker or speaker who is pointed by the first speaker. The first speaker sometimes calls the second speaker by the name of the second speaker over "you". 3) Third personal deixis, Deixis, which functions to point person outside the conversation.

In Japanese Personal deixis consists of three kinds [2].

- Watashi or the first person deixis example:

私が電話したのは (quoted: JLPT N5 Examples)

Watashi ga denwashita no wa ..... (it is I who called)

- Anata or the second person deixis example:

あなたは何歳ですか? (quoted: HiNative)

Anata wa nan sai desuka? (How old are you)

- Boku no Kanojo or the third person example :

僕の彼女はカナダへいってしまった。(quoted: JapanDict)

Boku no Kanojo wa Kanada e itte shimatta. (She has gone to Canada) 


\section{METHOD}

This paper is a result of a descriptive qualitative study. It uses the listening method to get the data. The technique to collect the data is listening, involving, and speaking. In this paper, it also uses the video of kaiwa or Japanese Conversation practice of the 2018/2019 fifth semester students of Japanese Education Program in UNNES, especially the conversation in chapter 7 of 中級から学ぶ日本語 or Chukyuu Kara Manabu Nihongo book as module. The writer chose chapter 7 because the indicator of this chapter is making dialogue in pairs and by group based on the role-play.

\section{RESULT AND DISCUSSION}

In chapter 7 of 中級から学ぶ日本語 or Chukyuu Kara Manabu Nihongo book, students were asked to make dialogue based on the role play. The situation for role-play is the customer has been waiting for the order for 20 minutes. In the dialogue, the paperer use "S" initial for the speaker or students.

\section{FIRST, SECOND, AND THIRD PERSONAL DEIXIS (FIRST GROUP)}

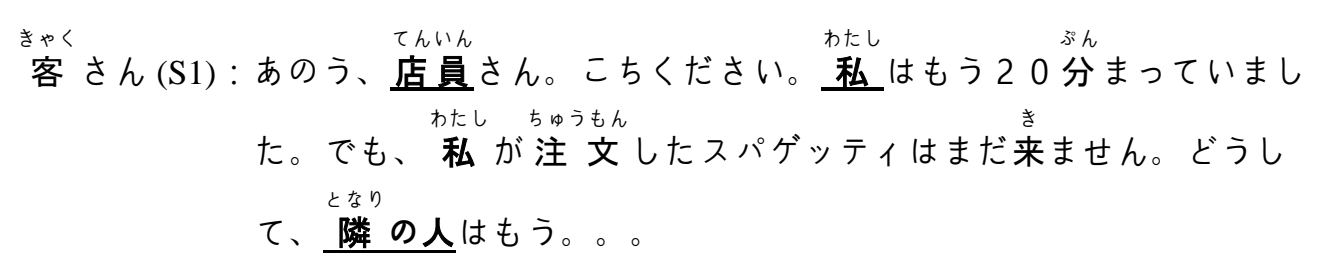

Thいh

店員さん(S2)：もうしわけございません。もうすぐ、スパゲッティを料理

します。

Kyaku-san: anou, tenin-san. Kochi kudasai. Watashi wa mou 20 pun matteimashita. Demo, watashi ga chuumon shita supageti wa mada kimasen. Doushite tonari no hito wa mou,,,,

Tenin-san : :moushiwakegozaimasen. Mousugu, supagetti o ryouri shimasu

Translation:

Customer: Excuse me, waitress. Come here, please. I have been waiting for 20 minutes. But my spaghetti has not come yet. Why the next person is already.

Waitress: So sorry. Will be cooked soon.

Analysis:

Based on the dialogue above, first personal deixis is 私/watashi, which means "I", refers to the first speaker or the speaker itself of the dialogue. S1 as the costumer role, uses watashi word because watashi itself uses in every formal circumstance, especially if both speakers do not know each other. 
Second personal deixis based on the dialogue above is 店員さh/tenin-san, which means "waiter' is a person who pointed by the first speaker in the dialogue. Tenin-san is similar to あなたlanata or you in Japanese.

The third personal deixis is 隣の人/tonari no hito, which means the next person refers to the person outside the dialogue. In Japanese, tonari no hito is similar to その人/sono hito means that person.

\section{FIRST, SECOND, AND THIRD PERSONAL DEIXIS (SECOND GROUP)}

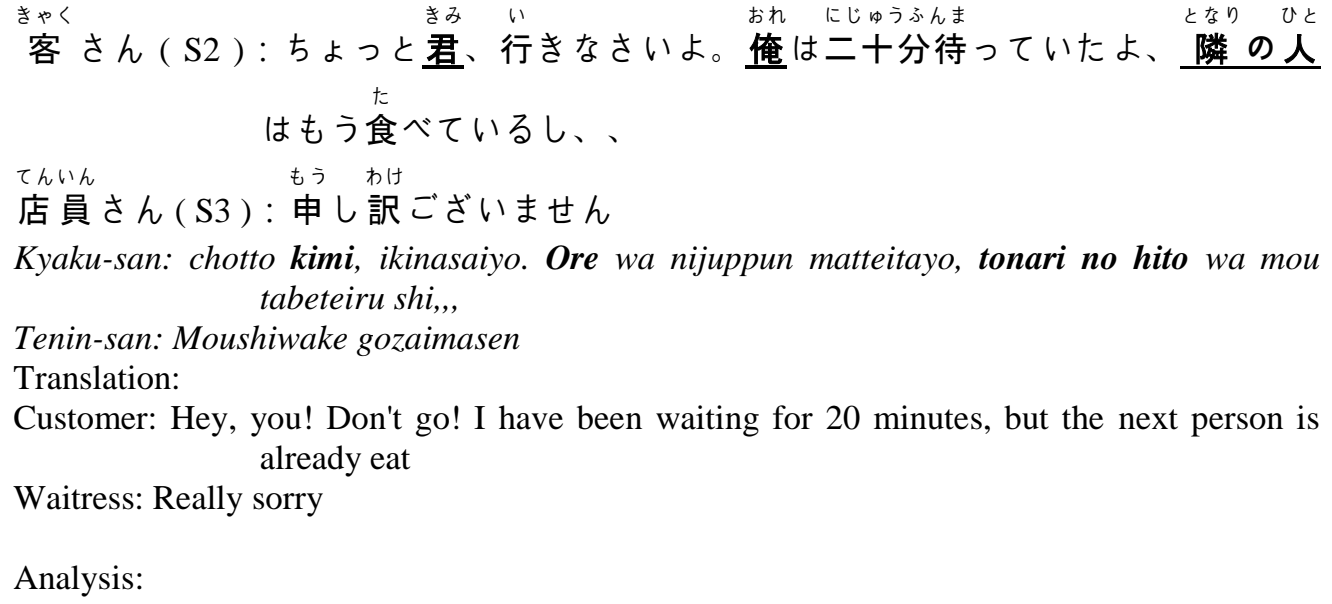

Customer: Hey, you! Don't go! I have been waiting for 20 minutes, but the next person is already eat

Waitress: Really sorry

Analysis:

First personal deixis: Based on the dialogue above, 俺/ore, which also means 'I' refer to the first speaker of the dialogue. However, 'ore' always used in the non-formal situation. Especially when the first speaker's social status is higher than the second person.

Second personal deixis: Based on the dialogue above, 君/kimi, which also means "you" refers to the second speaker. Kimi is always used in non-formal circumstances. Especially the status of the customer itself is higher than the waitress.

Third personal deixis: Based on the dialogue above, 隣の人/tonari no hito, which means the next person refers to the person outside the dialogue. In Japanese, tonari no hito is similar to その人/sono hito means that person.

\section{CONCLUSION}

Referring to the results of data analysis, personal deixis used by the fifth semester students of the Japanese Education Department in UNNES are revealed below. While their usage depends on the status of the speakers and circumstances.

\section{a. First personal deixis}

1 私/watashi means "I". Watashi itself uses in every formal circumstance. Especially if both speakers do not know each other. 
2 俺/ore means "You". ore always used in a non-formal situation. Especially when the first speaker's social status is higher than the second person.

\section{b. Second personal deixis}

1 店員さ ん/tenin-san means “The Waitress”. Is a person whom pointed by the first speaker in the dialogue. Tenin-san is similar with あなたlanata or you in Japanese.

2 君/kimi means "You". Kimi is always used in non-formal circumstances. Especially the status of the customer itself is higher than the waitress.

\section{c. Third personal deixis}

隣の人/tonari no hito means next person. It is a person outside the dialogue. In Japanese, tonari no hito is similar to その人/sono hito means that person.

\section{REFERENCE}

[1] R. Arai, Chukyu kara manabu nihongo. Kenkyusha, 2004.

[2] S. C. Levinson, Pragmatics. Cambridge University Press, 1983. 